DE

M E D I C I N A

T R O P I C A L

$\mathrm{DE}$

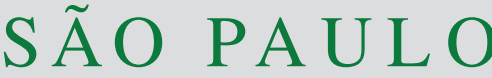

JOURNAL OF THE SÃO PAULO INSTITUTE OF TROPICAL MEDICINE

'Secretaria de Saúde do Paraná, $3^{\text {a }}$ Regional de Saúde, Seção da Vigilância Epidemiológica, Ponta Grossa, Paraná, Brazil

2Universidade Federal do Paraná, Complexo Hospital de Clínicas, Unidade de Vigilância à Saúde, Serviço de Epidemiologia, Curitiba, Paraná, Brazi

'Universidade Estadual de Maringá, Departamento de Análises Clínicas e Biomedicina, Maringá, Paraná, Brazil

Correspondence to: Simone Sardeto Valloto Dalazoana

Secretaria de Saúde do Paraná, $3^{\text {a }}$ Regional de Saúde, Seção da Vigilância Epidemiológica, Rua Dr. Paula Xavier, 743, Estrela, CEP 84040-010, Ponta Grossa, PR, Brazil

Tel: +55 423219 9848, +55 44 9984-8078

E-mail: sivalloto@ hotmail.com

Received: 4 November 2020

Accepted: 4 March 2021

\section{Challenges faced by health workers in the use of the directly observed treatment (DOT) for tuberculosis}

\author{
Simone Sardeto Valloto Dalazoana ${ }^{(1)}$, Betina Mendez Alcântara Gabardo ${ }^{(i)}$, \\ Rosilene Fressatti Cardoso 3
}

\section{ABSTRACT}

Tuberculosis is a worldwide public health problem, which, even with available treatment, continues to cause deaths worldwide. One of the obstacles to control the disease is the multifactorial difficulty of patients to adhere to treatment, in addition to the difficulty of health workers in circumventing barriers to implement strategies such as the directly observed treatment (DOT). The aim of this study is to analyze the performance and challenges faced by health workers in the use of DOT in tuberculosis. This is a descriptive, quali-quantitative study using data from interviews with primary-care professionals working in nine municipalities of Parana State, Brazil. The professionals answered a questionnaire containing four closed questions about DOT and an open question related to their professional opinion about the strategy. Quantitative data were entered into a spreadsheet and statistically propagated. Qualitative data were treated from the transcription of statements, subsequently submitted to content analysis. Of the 387 professionals interviewed, at least $58.9 \%$ had some knowledge about DOT. Among the main challenges faced by the professionals are: lack of user commitment to treatment (48.3\%), users' difficulty in attending the basic health clinics (BHC) (31.4\%), professionals' difficulty to reach the place where patients are treated (8.8\%), insufficient staff / lack of human resources $(4.1 \%)$ and use of illicit drugs by patients (3.9\%). Blaming the user and the lack of resources are the main highlights, in addition to issues such as the professionals' lack of access and knowledge that are highlighted by the difficulty of patients to adhere to the treatment of tuberculosis according to the participants' statements. The issues were raised by health workers manifestations involving adherence to treatment according to the DOT in the studied health region. It is possible, in this context, to observe the need for improvement in the knowledge of professionals with regard to the DOT, the importance of their bond with patients and families and the recognition of the part of responsibility that belongs to the health team on guaranteeing treatment.

KEYWORDS: Tuberculosis. Directly Observed Treatment. Health professionals. Primary health care.

\section{INTRODUCTION}

Tuberculosis (TB) is considered a neglected disease and a worldwide public health problem, ranking second among causes of death from infectious diseases worldwide $^{1}$. In Brazil, in 2014, the incidence of TB reached 34.1 cases per 100,000 inhabitants, being the $3^{\text {rd }}$ most frequent cause of death from infectious diseases and the leading cause of mortality among people infected with Human Immunodeficiency Viruses (HIV) ${ }^{2}$.

TB treatment is complex and lengthy, using different drugs, and lasting up to 6 months, even after the patient's clinical recovery. For these reasons, treatment 
abandonment is frequent and can lead to the emergence of resistant forms of Mycobacterium tuberculosis, which can be an obstacle to disease control ${ }^{1}$. One of the strategies against this obstacle is the recommendation by the World Health Organization (WHO) to implement directly observed short-course treatment (DOTS) ${ }^{3}$.

At the national level, the Brazilian Ministry of Health has been active in TB control since 2003, when TB was designated a priority public health problem to be tackled. Since then, the status of priority disease has strongly stimulated the organization and participation of the civil society in the social control of TB ${ }^{4}$. Both actions, WHO's DOTS and TB control by the Ministry of Health, consist of ensuring regular and correct chemotherapy based on the daily supervision of medication use ${ }^{5}$.

In this context, the following treatment modalities are considered: at home, in health facilities, or shared ${ }^{4}$. The choice of therapeutic modality is important and should be conducted jointly by the health team and the patient. However, the organizational logic in several TB care services follows strict rules, established by international epidemiological methods for the control of the disease and mainly, of the patient, whose autonomy is not considered in the therapeutic care process ${ }^{6}$.

Factors such as forgotten doses, lack of information about the disease, use of alcohol and other drugs, sociodemographic aspects, low income and schooling, HIV coinfection, having experienced side effects of antiTB drugs, and improvement of symptoms are significantly associated with non-adherence to TB treatment ${ }^{7,8}$. In this sense, directly observed treatment (DOT) could directly influence the number of cures and prevent multidrugresistant $\mathrm{TB}^{9}$, especially when performed by a professional the patient trusts ${ }^{10,11}$. The DOT brings professionals closer to the social context of individuals, establishing links between health services, patients and families ${ }^{4}$. However, the practice must be improved to encourage the user's autonomy in this process, allowing him to participate in discussions about treatment, giving space to individual's particularities and needs in the course of treatment ${ }^{12}$.

Unfortunately, nowadays, the lack of involvement, sensitivity, awareness and technical skills, together with the high turnover of team members in the health system ${ }^{13}$ and the movement of more skilled professionals to the private sector, are some of the problems faced by the Brazilian Unified Health System ${ }^{14}$ that hinder the smooth functioning of specific programs, such as those for TB. In this sense, proposals for humanization in health lead to the rethinking of the process of training professionals, as it is still centered on technical, rational, and individualized learning ${ }^{15}$.

As far as we know, there is a significant gap in terms of investigations on the effectiveness of DOT from the point of view of all the professionals who make up the primary healthcare teams, a fact that justified the development of this study. Therefore, our aim was to analyze the performance and challenges faced by health workers in the use of DOT in TB.

\section{MATERIALS AND METHODS}

This was a descriptive study with a quali-quantitative approach, developed in the municipalities covered by the $15^{\text {th }}$ Health Regional of Parana State, Brazil, involving a survey of operational and epidemiological data after the implementation of the DOT strategy in the State.

The $15^{\text {th }}$ Health Regional of Parana is composed of 30 municipalities with an estimated population of 782,186 inhabitants. In 2014, 17 municipalities had TB cases reported on the SINAN NETWORK, of these, nine municipalities participated in this study. Municipalities whose municipal health managers did not confirm their acceptance to participate in the study were excluded by requesting authorization to conduct the study after three attempts to contact them via email or phone.

The study included medical professionals, nurses, community health agents (CHA), endemic control agents (ECA), pharmacists, dentists, nursing assistants or technicians and oral health assistants or technicians (OHA). The exclusion of professionals was due to the failure to correctly complete the Free and Informed Consent Term or for not having returned the questionnaire within the established period (professionals on vacation, leave or medical certificate during the data collection period).

Data collection took place between June and August 2015 through individual questionnaires delivered to health workers after the participants' consent. Firstly, the questionnaire contained questions about the professional's profile containing age, profession and length of experience, then the questionnaire had four closed questions related to the professionals' knowledge and opinion about the guidelines and difficulties related to the DOT, and finally, one open question related to the professional's perception of DOT, pointing out difficulties and/or facilities in the execution.

The quantitative data obtained were entered into a Microsoft Excel 2010 spreadsheet, analyzed using the SPSS (version 25) statistical software (SPSS Inc, Chicago, IL, USA), and then organized into relative-frequency tables. The Shapiro-Wilk normality test was applied, which indicated an abnormal distribution of the data. To this end, the Kruskal-Wallis non-parametric test was applied comparing the answers of DOT-related questions with the 
variables length of experience and profession. Associations with $\mathrm{p}<0.05$ were considered significant.

For the analysis of qualitative data, the answers were transcribed in full and submitted to thematic content analysis ${ }^{16}$. The initial organization of the material comprised the acquisition and identification of the messages by free-floating reading, followed by a thorough reading of the interviews.

Subsequently, the coding of the data began. The raw data were transformed and aggregated into units, allowing a description of the characteristics of the content ${ }^{17}$. After the coding was completed, the thematic analysis and the categorization were started, based on the themes found.

The study was developed in accordance with the guidelines established by the Resolution 466/ 2012 of the Brazilian National Health Counci ${ }^{16}$ and approved by the Standing Ethics Committee of the Workers' Hospital of the Parana State Health Secretariat under opinion N ${ }^{\circ} 941.463$ of January $28^{\text {th }}, 2015$. All the participants of the study signed an Informed Consent Form.

\section{RESULTS}

We interviewed 387 professionals from 13 municipalities under the jurisdiction of the $15^{\text {th }}$ Regional Division of Parana State Health Secretariat, with a mean age of $41.2 \pm 10.3$ years. Among the surveyed professionals, $33.9 \%(\mathrm{n}=131)$ were $39-48$ years old, $59.4 \%(\mathrm{n}=230)$ were CHAs, and $44.4 \%(n=172)$ had been working in their current positions for 10 years or more (Table 1).

The study was able to show that the basic knowledge about the DOT guidelines is understood by more than half of the professionals in two specific questions on the topic. About that, $58.9 \%(\mathrm{n}=228)$ stated that DOT for TB consists of daily doses (Monday through Friday) of medication under the supervision of the health professional, enabling interaction, shared responsibility, and learning; and $76.0 \%$ $(\mathrm{n}=294)$ stated that DOT is available in their health clinic five days a week.

Most professionals have also recognized that the responsibility for DOT lies with the nursing team and the CHA. Therefore, the professionals most often mentioned as responsible for DOT for TB were CHAs $(\mathrm{n}=169,43.7 \%)$, followed by nurses $(n=147,38 \%)$ and nursing technicians and/or assistants ( $\mathrm{n}=46,11.9 \%)$ (Table 2).

As for the difficulties in performing the DOT, the most often mentioned by the studied population was the lack of users' commitment to the treatment or non-adherence to it $(\mathrm{n}=187,48.3 \%)$. According to the interviewees, transportation of the user to the BHC was the second most often mentioned difficulty $(\mathrm{n}=113,29.2 \%)$, and ranking
Table 1 - Profile distribution of participating professionals from 13 municipalities of Parana State, Brazil, 2015. $(n=387)$

\begin{tabular}{lcc}
\hline Variables & $\mathrm{n}$ & $\%$ \\
\hline Age group (years) & 38 & \\
18 to 28 & 111 & 28.7 \\
29 to 38 & 131 & 33.9 \\
39 to 48 & 87 & 22.5 \\
49 to 58 & 20 & 5.2 \\
59 years or older & & \\
Profession & 230 & 59.4 \\
Community health agent & 47 & 12.1 \\
Nurse & 46 & 11.9 \\
Nursing assistant/technician & 27 & 7.0 \\
Physician & 12 & 3.1 \\
Dentist & 11 & 2.9 \\
Oral health assistant/technician & 7 & 1.8 \\
Environmental agent & 3 & 0.8 \\
Pharmacist & 2 & 0.5 \\
Receptionist & 2 & 0.5 \\
Endemic control agent & 172 & 44.4 \\
Length of experience & & \\
Less than 5 years & & \\
5 to 10 years & & 36.4 \\
10 years or more & & 19.1 \\
\hline
\end{tabular}

third and fourth were difficulty of transporting professionals to the patient's location of DOT ( $\mathrm{n}=34,8.8 \%$ ) and use of illicit drugs by patients $(n=15,3.9 \%)$, respectively (Table 2$)$.

In the currently studied population, there was a statistically significant correlation $(p=0.007)$ between the length of experience and the professional responsible for DOT at the BHC (Table 3). The person responsible for DOT, considering the variable "profession", has also shown a correlation ( $p=0.089)$, albeit it did not reach statistically significance (Table 4). The other answers correlating DOT with the variables profession and length of experience showed no significant differences.

Regarding the opinion of the interviewed health professionals about DOT in patients with TB, 206 (53.2\%) described DOT as being "good," "great," "important," "necessary," or "a good strategy." Of the interviewees, $29(7.5 \%)$ agreed with DOT and their written answers mentioned factors related to the Singular Therapeutic Project; seventy-seven (19.9\%) responded positively, but with reservations, mainly regarding the patient adherence to treatment; forty-one professionals $(10.6 \%)$ did not agree with this modality of treatment; and $34(8.8 \%)$ did not answer or did not know how to answer this question. 
Table 2 - Distribution of answers related to DOT given by interviewed professionals from 13 municipalities of Parana State, Brazil, 2015. $(n=387)$.

\begin{tabular}{|c|c|c|}
\hline Questions & $\mathrm{n}$ & $\%$ \\
\hline \multicolumn{3}{|l|}{ Understanding about DOT } \\
\hline $\begin{array}{l}\text { Monday to Friday, enabling interaction, shared responsibility, and learning by nurses, nursing } \\
\text { technicians and assistants, and CHAs }\end{array}$ & 228 & 58.9 \\
\hline $\begin{array}{l}\text { Monday to Sunday, enabling interaction, shared responsibilityand learning by nurses, nursing } \\
\text { technicians and assistants, and CHAs }\end{array}$ & 135 & 34.9 \\
\hline $\begin{array}{l}\text { Three times a week, enabling interaction, shared responsibility, and learning by nurses, nursing } \\
\text { technicians and assistants, and CHAs }\end{array}$ & 11 & 2.8 \\
\hline $\begin{array}{l}\text { Once a month, enabling interaction, shared responsibility, and learning by nurses, nursing } \\
\text { technicians and assistants, and CHAs }\end{array}$ & 4 & 1.0 \\
\hline "I don't know how to answer" & 9 & 2.3 \\
\hline \multicolumn{3}{|l|}{ DOT conducted at the BHC } \\
\hline Yes, 5 days a week & 294 & 76.0 \\
\hline Yes, every day of the week (Monday through Sunday) & 33 & 8.5 \\
\hline Yes, 3 days a week & 22 & 5.7 \\
\hline "I don't know how to answer" & 16 & 4.1 \\
\hline No DOT is conducted & 13 & 3.4 \\
\hline It depends on the availability of professionals & 9 & 2.3 \\
\hline \multicolumn{3}{|l|}{ Responsible for the DOT } \\
\hline $\mathrm{CHA}$ & 169 & 43.7 \\
\hline Nurse & 147 & 38.0 \\
\hline Nursing assistant or technician & 41 & 10.6 \\
\hline Other & 17 & 4.4 \\
\hline Physician & 8 & 2.1 \\
\hline No DOT is conducted & 5 & 1.3 \\
\hline \multicolumn{3}{|l|}{ Main difficulties for DOT } \\
\hline Lack of user commitment to treatment & 187 & 48.3 \\
\hline Difficulty of transportation of the user to the $\mathrm{BHC}$ & 122 & 31.4 \\
\hline Difficulty of transportation of professionals to the patients' location for DOT & 34 & 8.8 \\
\hline Insufficient staff/lack of human resources & 16 & 4.1 \\
\hline Patients using illicit drugs & 15 & 3.9 \\
\hline Unfavorable physical facilities at the $\mathrm{BHC}$ & 8 & 2.1 \\
\hline DOT is not considered a priority at the BHC & 2 & 0.5 \\
\hline Lack of support from the management & 1 & 0.3 \\
\hline No DOT is conducted & 1 & 0.3 \\
\hline Other & 1 & 0.3 \\
\hline
\end{tabular}

DOT = Directly Observed Treatment; $\mathrm{CHA}=$ community health agents; $\mathrm{BHC}=$ basic health clinic.

It was found that most professionals understand the importance of the application of DOT: - "DOT is of paramount importance, given that many patients give up or abandon treatment before the end" (Nurse -28 years old). However, the meaning of adherence for the interviewed professionals is closely associated with just taking or not taking the medication, rather than with building a bond with the environment in which the patient is inserted:
- Conducting DOT improves the patient adherence and reduces the rate of abandonment, avoiding the emergence of multidrug-resistant bacilli and the transmission of the disease" (Pharmacist - 42 years old) and: - "I think it is great, because this way we can ensure the patient's cure by making sure that the patient takes the medicine every day" (CHA - 34 years old). 
Table 3 - Knowledge of professionals about DOT according to their length of experience in basic health clinics in 13 municipalities of Parana State, Brazil, $2015(n=387)$.

\begin{tabular}{|c|c|c|c|c|c|}
\hline \multirow[b]{2}{*}{ Questions } & \multicolumn{4}{|c|}{ Length of experience (years) } & \multirow[b]{2}{*}{$p$ value } \\
\hline & $\begin{array}{c}\geq 10 \\
\mathrm{n}(\%)\end{array}$ & $\begin{array}{l}5-10 \\
n(\%)\end{array}$ & $\begin{array}{c}<5 \\
\mathrm{n}(\%)\end{array}$ & $\begin{array}{c}\text { Total } \\
\mathrm{n}\end{array}$ & \\
\hline \multicolumn{6}{|l|}{ Understanding DOT } \\
\hline $\begin{array}{l}\text { Monday through Friday, enabling interaction, shared responsibility, } \\
\text { and learning by nurses, nursing technicians and assistants, and } \\
\text { CHAs }\end{array}$ & $101(44)$ & $43(19)$ & $84(37)$ & 228 & 0.884 \\
\hline $\begin{array}{l}\text { Monday through Sunday, enabling interaction, shared responsibility, } \\
\text { and learning by nurses, nursing technicians and assistants, and } \\
\text { CHAs }\end{array}$ & $67(50)$ & $26(19)$ & $42(31)$ & 135 & \\
\hline Others & $4(17)$ & $5(21)$ & $15(62)$ & 24 & \\
\hline \multicolumn{6}{|l|}{ How DOT is carried out at the BHC } \\
\hline Every day from Monday to Sunday & $16(49)$ & $6(18)$ & $11(33)$ & 33 & 0.310 \\
\hline Five days a week & $134(46)$ & $57(19)$ & $103(35)$ & 294 & \\
\hline Three days a week & $9(41)$ & $6(27)$ & $7(32)$ & 22 & \\
\hline Others & $13(34)$ & $5(13)$ & $20(53)$ & 38 & \\
\hline \multicolumn{6}{|l|}{ Responsible for DOT at the BHC } \\
\hline $\mathrm{CHA}$ & $61(36)$ & $43(25)$ & $65(39)$ & 169 & 0.007 \\
\hline Nursing assistant or technician & $22(54)$ & $6(14)$ & $13(32)$ & 41 & \\
\hline Nurse & $75(51)$ & $23(16)$ & $49(33)$ & 147 & \\
\hline Others & $14(47)$ & $2(6)$ & $14(47)$ & 30 & \\
\hline \multicolumn{6}{|l|}{ Difficulties in carrying out DOT } \\
\hline Patient transportation to the $\mathrm{BHC}$ & $52(46)$ & $19(17)$ & $42(37)$ & 113 & 0.728 \\
\hline Transportation of professionals to the patient's location & $18(53)$ & $6(18)$ & $10(30)$ & 34 & \\
\hline Lack of human resources & $7(44)$ & $3(19)$ & $6(37)$ & 16 & \\
\hline Lack of user commitment & $79(42)$ & $42(22)$ & $66(35)$ & 187 & \\
\hline Patients using illicit drugs & $9(60)$ & $2(13)$ & $4(27)$ & 15 & \\
\hline Others & $7(32)$ & $2(9)$ & $13(60)$ & 22 & \\
\hline Total & $172(44)$ & $74(19)$ & $141(37)$ & 387 & \\
\hline
\end{tabular}

DOT = Directly Observed Treatment; $\mathrm{CHA}=$ community health agents; $\mathrm{BHC}=$ basic health clinic.

The statements has also addressed issues of fragility in the care relations between health professionals and users: - "Unfortunately, it is a necessary action, in view of the results obtained, but it demonstrates the lack of commitment of the population to individual and collective health" (Nurse - 32 years old); - "It is important that the team does its share, but it is essential that the family also participates by collaborating with the administration of the medication" (CHA - 37 years old); and:- "This is an effective method for controlling the tuberculosis treatment while maintaining treatment integrity and reinforcing a good relationship between the health system and the patients-and family" (Physician -30 years old).

The need for more effective and humanized treatment of TB patients was described: - "I believe that a screening could be carried out to assess the level of understanding of the disease and the socioeconomical family structure. If difficulties are observed, yes, DOT would be of utmost importance, otherwise one could do just the weekly monitoring." (Nurse -25 years old).

It is possible to observe the need for training (continuing education) or even formal teaching about TB and drugs, which are considered indispensable in the training of health professionals, with a view to providing qualified assistance to this population: "I think it is good, but I think that for it to be done, the professional needs to have attended a course on the subject" (CHA - 31 years old) and "It is a very important treatment and a way for the patient not to abandon the treatment, because not only is the medication very strong, but there are also patients with chemical or alcoholic dependence who do not want to take the medication" (CHA -51 years old $)$. 
Table 4 - Knowledge of professionals working in basic health clinics about DOT in 13 municipalities of Parana State, Brazil, 2015, according to their professional category $(n=387)$.

\begin{tabular}{|c|c|c|c|c|c|c|}
\hline \multirow[b]{2}{*}{ Questions } & \multicolumn{5}{|c|}{ Profession } & \multirow[b]{2}{*}{$P$ value } \\
\hline & $\begin{array}{l}\mathrm{CHA} \\
\mathrm{n}(\%)\end{array}$ & $\begin{array}{c}\text { Nurse } \\
\mathrm{n}(\%)\end{array}$ & $\begin{array}{c}\text { Physician } \\
\text { n (\%) }\end{array}$ & $\begin{array}{c}\text { Dentist } \\
\mathrm{n}(\%)\end{array}$ & $\begin{array}{c}\text { Others } \\
n(\%)\end{array}$ & \\
\hline \multicolumn{7}{|l|}{ Understanding DOT } \\
\hline $\begin{array}{l}\text { Monday through Friday, enabling interaction, shared } \\
\text { responsibility, and learning by nurses, nursing } \\
\text { technicians and assistants, and CHAs. }\end{array}$ & $134(59)$ & $59(26)$ & $17(8)$ & $10(4)$ & $8(3)$ & 0.412 \\
\hline $\begin{array}{l}\text { Monday through Sunday, enabling interaction, } \\
\text { shared responsibility, and learning by nurses, nursing } \\
\text { technicians and assistants, and CHAs. }\end{array}$ & $78(58)$ & $33(24)$ & $9(7)$ & $10(7)$ & $5(4)$ & \\
\hline Others & $18(76)$ & $1(4)$ & $1(4)$ & $2(8)$ & $2(8)$ & \\
\hline \multicolumn{7}{|l|}{ How DOT is carried out at the BHC } \\
\hline Every day from Monday to Sunday & $24(73)$ & $5(15)$ & $1(3)$ & $3(9)$ & $0(0)$ & 0.375 \\
\hline Five days a week & $171(58)$ & $78(26)$ & $21(7)$ & $11(4)$ & $13(5)$ & \\
\hline Three days a week & $12(54)$ & $5(23)$ & $2(9)$ & $2(9)$ & $1(5)$ & \\
\hline Others & $23(60)$ & $5(13)$ & $3(8)$ & $6(16)$ & $1(3)$ & \\
\hline \multicolumn{7}{|l|}{ Responsible for DOT at the BHC } \\
\hline $\mathrm{CHA}$ & $108(64)$ & $40(24)$ & $9(5)$ & $5(3)$ & $7(4)$ & 0.089 \\
\hline Nursing assistant or technician & $20(49)$ & $14(34)$ & $4(10)$ & $1(2)$ & $2(5)$ & \\
\hline Nurse & $85(60)$ & $35(24)$ & $12(8)$ & $12(8)$ & $3(2)$ & \\
\hline Others & $17(57)$ & $4(13)$ & $2(7)$ & $4(13)$ & $3(10)$ & \\
\hline \multicolumn{7}{|l|}{ Difficulties in carrying out the DOT } \\
\hline Patient transportation to the $\mathrm{BHC}$ & $58(51)$ & $30(26)$ & $10(9)$ & $8(7)$ & $7(6)$ & 0.276 \\
\hline Transportation of professionals to the patient's location & $22(65)$ & $9(26)$ & $2(6)$ & $0(0)$ & $1(3)$ & \\
\hline Lack of human resources & $7(44)$ & $5(31)$ & $1(6)$ & $2(12)$ & $1(6)$ & \\
\hline Lack of user commitment & $120(64)$ & $41(22)$ & $12(6)$ & $9(5)$ & $5(3)$ & \\
\hline Patients using illicit drugs & $9(60)$ & $4(27)$ & $0(0)$ & $1(7)$ & $1(7)$ & \\
\hline Others & $14(64)$ & $4(18)$ & $2(9)$ & $2(9)$ & $0(0)$ & \\
\hline Total & $230(60)$ & $93(24)$ & $27(7)$ & $22(6)$ & $15(4)$ & \\
\hline
\end{tabular}

DOT = Directly Observed Treatment; CHA = community health agents; BHC = basic health clinic; "Nurse" also includes nursing assistants and technicians; "Dentist" also includes oral health assistants and technicians.

\section{DISCUSSION}

As a first point related to the professional's performance in the DOT, the professionals' knowledge about essential DOT points highlighted in the guidelines seems to be understood by the workers interviewed. Even so, an important part of the participants was not able to show adequate knowledge about the DOT guidelines for TB, allowing the understanding that there are gaps in this process.

The description of DOT for TB selected by the majority of professionals $(n=228,58.9 \%)$ was in agreement with that published by the Brazilian Ministry of Health, which consists of taking medication from Monday to Friday under the supervision of a health professional, resulting in interaction, shared responsibility, and learning by all the actors (nurses, nursing technicians and assistants, and $\mathrm{CHAs})^{6}$. Despite their professional categories being emphasized in the official description of DOT, nurses, nursing technicians and assistants, and CHAs did not show greater knowledge of the definition of DOT when compared to other professionals who do not work so directly with the strategy $(\mathrm{p}=0.412)$.

Studies from other countries that verified the knowledge of health workers point to gaps in practice and knowledge related to DOT, indicating urgency in adopting innovations that address perceived barriers and improve the knowledge of professionals involved in the practice ${ }^{18-20}$. One of the main focus of discussion in the study by Choowong $\mathrm{et} \mathrm{al} .^{20}$ addresses the need for professionals who are able to 
guide and monitor patients with a focus on autonomy in adhering to treatment. In other words, the discussion is not necessarily about guaranteeing that medication is taken in an authoritarian way, but from the bond, bringing the responsibility and autonomy of care to the patient's daily life.

Regarding the perception of the professional responsible for DOT, the answers showed that most understand that nursing professionals and CHAs are involved in this process. The statistically significant value $(p=0.007)$ shows that professionals with more than 10 years of experience have better knowledge of the person responsible for DOT at the BHC. A similar study carried out with CHAs has also shown that the length of experience influences the professionals' knowledge about DOT $^{21}$. Additionally, when evaluating professional categories, the results show that CHAs and the nursing team have a better understanding of their responsibility in conducting DOT, even though the difference is not statistically significant $(\mathrm{p}=0.089)$.

The functioning of the program as a whole depends on the development of actions that are specific to each professional category ${ }^{5}$; therefore, it is important that each member of the team knows their actual assignments for carrying out DOT. The protocol defines specific attributions for each professional category in TB care, including the CHAs supervising drug intake, according to the planning for the team, under the supervision of nursing professionals ${ }^{6}$.

In the work of family health teams, as in all primarycare work, clinical activities depend on professionals with different training (physicians, nurses and others), but they also depend on the interdisciplinary interaction between these different forms of clinical practice, an interaction that has its most significant moment in team work. It is essential to include the multiprofessional health team to face the problem, which requires a broad structure of knowledge about health promotion and prevention for the benefit of the entire society ${ }^{22,23}$.

As for the difficulties in DOT continuity perceived by the professionals, the lack of user commitment to treatment $(\mathrm{n}=187,48.3 \%)$ stood out, along with difficulties in transporting patients to the BHC $(\mathrm{n}=122$, $31.4 \%$ ). According to the literature ${ }^{24}$, there are multiple causes for DOT interruption and failure, which can be classified as structural (poverty, gender and discrimination), user-related (motivation, knowledge, beliefs, attitude, and interpretation of the health and disease process), social (family, community, and social support networks), and health service-related (organization of care and treatment, evolution of the disease and adverse effects).

Some authors suggest that approaches that do not consider the dialogue between user and professional tend to blame only the user for their health status, which makes the user responsible for not adhering to treatment ${ }^{25}$. However, professionals also play a fundamental role in the treatment, especially regarding the user embracement, which can positively assist in bonding and treatment success ${ }^{25}$. In this sense, it is necessary to broaden the understanding of treatment adherence to be able to discuss the treatment in a more just and less blaming manner ${ }^{26}$.

According to the DOT guidelines, adherence to treatment is a two-wayprocess, as it depends on the commitment of the patient and the health team ${ }^{4}$. Blaming one or the other, that is, the user or the team, shows the difficulty in ensuring adequate treatment for patients with tuberculosis. Determining adherence to treatment as the patient's exclusive autonomous action makes him the only one to blame when there is treatment failure, disregarding the context in which he lives including his weaknesses; on the other hand blaming treatment adherence only to the bond built by the team with the patient, is to blame the health team if there is treatment failure, disregarding the organization of the service and working conditions ${ }^{26}$.

In this multifactor context, the therapeutic project is a strategy that aims to overcome these challenges. Built in meetings, it requires the use of educational actions aimed at promoting the autonomy and participation of the patients and their families in the treatment ${ }^{27}$. During the process of supervising the therapeutic action, it is possible to observe that a relationship is established between the patient and the health professional, permeated by affectivity and availability of time for conversation, characterizing a form of humanized care. Therefore, humanization is an indispensable tool, in which the professional uses communication, shared decisionmaking and support to patient autonomy with regard to his or her treatment and health ${ }^{28}$.

However, the statements made by the professionals have shown an understanding of DOT based on issues strictly related to taking the medication, causing important issues in the individuals' biopsychosocial dimension to be sent to the background. The health worker's knowledge of the environment in which the patients are inserted and of their needs and singularities, is a factor that helps to identify complications during treatment, enabling new opportunities for interaction with the patients and their families ${ }^{29,30}$.

For these reasons, team qualification is a strategy to be used, and it was mentioned as necessary by the participants in this study. Continued qualification of the team in TB-related aspects strengthens healthcare and, through involvement with the patients, conveys a sense of security in the orientation and care of the professional, which may reduce the chances of treatment abandonment ${ }^{29}$. Additionally, updating the team allows professionals to 
be prepared for early detection of TB and to devise more successful action plans against the disease ${ }^{31}$.

A point that was highlighted in the speech of the professionals was to enable a "screening" of patients undergoing treatment, considering the understanding of the disease, family structure, socioeconomic condition, among others. In this sense, the need for daily monitoring in taking the medication would be determined, allowing a greater periodicity between visits to patients with better conditions. These possibilities are absent in the current guidelines, which are flexible only when the medication taking will be supervised (home, health service and shared) ${ }^{4}$.

As a limiting factor of the study, the difficulty in quantitatively evaluate different contexts experienced by these professionals stands out. Each municipality has its own peculiar characteristics regarding living conditions, sanitation, availability of jobs and education, access to services, structure and organization of services. Another relevant aspect is that patients, health professionals, and managers have different perspectives because each one's needs and requirements depend on their position in the service.

The main challenges in the implementation of DOT in this regional health division, from the point of view of health workers, are the lack of user commitment to the treatment and the difficulty in transporting patients to the BHC, of which: adherence to treatment, the user accountability in this scenario and factors that involve the lack of human and structural resources as well as difficulty of access are quite evident. Additionally, measures aimed at improving the knowledge of professionals about DOT also seem necessary, given the knowledge gaps identified in the study, in addition to fostering discussions that allow the assessment of the main difficulties related to users in the region, strategies to overcome them, the importance of promoting the bond beyond taking medication, and the recognition of the health team's responsibility in adhering to treatment. All these issues demand management skills from health professionals and administrators that will enable them to design mechanisms to conduct the process of reorganizing and planning actions and services according to the specificities of each social and cultural context where DOT is conducted.

\section{CONFLICT OF INTERESTS}

There is no conflict of interests.

\section{REFERENCES}

1. World Health Organization. Global tuberculosis report 2016. Geneva: WHO; 2016.
2. Brasil. Ministério da Saúde. Secretaria de Vigilância em Saúde. Detectar, tratar e curar: desafios e estratégias brasileiras frente à tuberculose. Bol Epidemiol. 2015;46:1-19.

3. Rodrigues L, Barreto M, Kramer M, Barata RD. Resposta brasileira à tuberculose: contexto, desafios e perspectivas. Rev Saude Publica. 2007;41 Suppl 1:1-2.

4. Brasil. Ministério da Saúde. Secretaria de Vigilância em Saúde. Departamento de Vigilância das Doenças Transmissíveis. Manual de recomendações para o controle da tuberculose no Brasil. $2^{\text {a }}$ ed. Atual. Brasília: Ministério da Saúde; 2019.

5. Santos TM, Nogueira LT, Santos LN, Costa CD. O acesso ao diagnóstico e ao tratamento de tuberculose em uma capital do nordeste brasileiro. Rev Enferm UERJ. 2012;20:300-5.

6. Brasil. Ministério da Saúde. Secretaria de Vigilância em Saúde. Departamento de Vigilância Epidemiológica. Tratamento diretamente observado (TDO) da tuberculose na atenção básica: protocolo de enfermagem. Brasília: Ministério da Saúde; 2011.

7. Souza AC, Silva ML, Mirando LN. Dificuldades na adesão do plano de tratamento pelo paciente com tuberculose. Cien Biol Saude Unit. 2017;4:297-312.

8. Ferreira MR, Bonfim RO, Siqueira TC, Orfão NH. Abandono do tratamento da tuberculose: uma revisão integrativa. Rev Enferm Contemp. 2018;7:63-71.

9. Thorn P. La tuberculosis: información y consejos para vencer la enfermedad. Geneva: WHO: Stop TB Partnership; 2007.

10. Mkopi A, Range N, Lwilla F, Egwaga S, Schulze A, Geubbels E, et al. Adherence to tuberculosis therapy among patients receiving home-based directly observed treatment: evidence from the united republic of Tanzania. PLoS One. 2012;7:e51828.

11. Queiroz EM, De-La-Torre-Ugarte-Guanilo MC, Ferreira KR, Bertolozzi MR. Tuberculosis: limitations and strengths of Directly Observed Treatment Short-Course. Rev Lat Am Enfermagem. 2012;20:369-77.

12. Sicsú AN, Gonzales RI, Mitano F, Sousa LO, Silva LM, Ballestero JG, et al. Nursing practices centered on individuals with tuberculosis: an interface with democracy. Rev Bras Enferm. 2019;72:1219-25.

13. Sá LD, Andrade MN, Nogueira JA, Villa TC, Figueiredo TM, Queiroga RP, et al. Implantação da estratégia DOTS no controle da tuberculose na Paraíba: entre o compromisso político e o envolvimento das equipes do programa saúde da família (19992004). Cienc Saude Colet. 2011;16:3917-24.

14. Nogueira JD, Ruffino-Netto A, Villa TC, Monroe AA, Lucca ME. Implantação da estratégia DOTS no controle da tuberculose em Ribeirão Preto, São Paulo (1998-2004). Bol Pneumol Sanit. 2006;14:141-4.

15. Medeiros LM, Batista SH. Humanização na formação e no trabalho em saúde: uma análise da literatura. Trab Educ Saude. 2016;14:925-51.

16. Bardin L. Analise de conteúdo. São Paulo: Edições 70; 2011. 
17. Brasil. Ministério da Saúde. Conselho Nacional de saúde. Resolução ${ }^{\circ}$ 196, de 10 de outubro de 1996. Aprova as diretrizes e normas regulamentadoras de pesquisas envolvendo seres humanos. Diário Oficial da União, 10 out. 1996.

18. Singh AR, Pakhare A, Kokane AM, Shewade HD, Chauhan A, Singh A, et al. 'Before reaching the last mile': knowledge, attitude, practice and perceived barriers related to tuberculosis directly observed therapy among ASHA workers in Central India: a mixed method study. J Epidemiol Glob Health. 2017;7:219-25

19. Noé A, Ribeiro RM, Anselmo R, Maixenchs M, Sitole L, Munguambe $\mathrm{K}$, et al. Knowledge, attitudes and practices regarding tuberculosis care among health workers in Southern Mozambique. BMC Pulm Med. 2017;17:2.

20. Choowong J, Tillgren P, Söderbäck M. Directly observed therapy providers' practices when promoting tuberculosis treatment in a local Thai community. Public Health Dev Ctries. 2018;4:45866.

21. Rocha GS, Lima MG, Moreira JL, Ribeiro KC, Ceccato MG, Carvalho WS, et al. Conhecimento dos agentes comunitários de saúde sobre a tuberculose, suas medidas de controle e tratamento diretamente observado. Cad Saude Publica. 2015;31:483-96.

22. Nascimento CV, Soares SM. Manejo integrado de tuberculose e diabetes: uma revisão integrativa. Rev Panam Salud Publica. 2019;43:e21.

23. Pereira AG, Escosteguy CC, Gonçalves JB, Marques MR, Brasil CM, Silva MC. Factors associated with death from tuberculosis and treatment default in a general hospital in the city of Rio de Janeiro, 2007 to 2014. J Epidemiol Infect Control. 2018;8:1-8.
24. Munro SA, Lewin SA, Smith HJ, Engel ME, Fretheim A, Volmink J. Patient adherence to tuberculosis treatment: a systematic review of qualitative research. PLoS Med. 2007;4:e238.

25. Freire AP, Stroschein KA, Nakata PT, Cicolella DA. Percepção da enfermagem sobre a adesão eo abandono do tratamento da tuberculose. Rev Enferm UFSM. 2020;10:1-18.

26. Zoboli E. Autonomia e coerção na justa medida do tratamento da tuberculose. Interface (Botucatu). 2016;20:760-2.

27. Araujo AS, Vieira SS, Lucena Junior B. Fatores condicionantes ao abandono do tratamento da tuberculose relacionados ao usuário e à equipe de saúde. Cad Saude Desenvolv. 2017;10:18-33.

28. O'Donnell MR, Daftary A, Frick M, Hirsch-Moverman Y, Amico KR, Senthilingam M, et al. Re-inventing adherence: toward a patient-centered model of care for drug-resistant tuberculosis and HIV. Int J Tuberc Lung Dis. 2016;20:430-4.

29. Sackser MA, Borges AM. Razões que levam os pacientes com tuberculose a abandonarem o tratamento: perspectivas do enfermeiro. Ver Enferm Atual. 2019;87 Suppl:1-10.

30. Chirinos NE, Meirelles BH, Bousfield AB. A relação das representações sociais dos profissionais da saúde e das pessoas com tuberculose com o abandono do tratamento. Texto Contexto Enferm. 2017;26:e5650015.

31. Macedo SM, Andrade RP, Souza CB, Andrade AS, Villa TC, Pinto ES. Estratégias para capacitação ao cuidado em tuberculose. Cogitare Enferm. 2016;21:01-08. 